\title{
Rhabdomyosarcoma in a child with nephrotic syndrome treated with cyclosporine: a case report with literature review
}

\author{
Huai-Chueh Gem Wu' ${ }^{1}$, Chao-Neng Cheng ${ }^{2}$, Jiann-Shiuh Chen ${ }^{2}$ and Yuan-Yow Chiou ${ }^{3,4^{*}}$ (D)
}

\begin{abstract}
Background: In patients with frequently relapsing nephrotic syndrome, immunosuppressive therapy such as cyclosporine are often required to maintain remission. Cyclosporine has been noted to have tumorgenesis effects. In this case report, we present a child with relapsing nephrotic syndrom developed a rhabdomyosarcoma on her tongue after adout 4 years of continual immunosuppressive therapy.

Case presentation: A 2-year-old female child had nephrotic syndrome (urine protein-creatinine ratio $749.1 \mathrm{mg} / \mathrm{mg}$; blood urea nitrogen $11 \mathrm{mg} / \mathrm{dL}$; serum creatinine $0.3 \mathrm{mg} / \mathrm{dL}$; and serum albumin $1.8 \mathrm{~g} / \mathrm{dL}$.) Proteinuria resolved on treatment with daily prednisolone for 4 weeks at the dose of $45 \mathrm{mg}(2.5 \mathrm{mg} / \mathrm{kg} / \mathrm{day})$ but recurred with taper from $25 \mathrm{mg} /$ day to $10 \mathrm{mg} /$ day. At least five more episodes of relapse occurred within about a 3-year period. After the third relapse, she was treated with prednisolone and cyclosporine (at initial dose of $50 \mathrm{mg} / \mathrm{day}[1.7 \mathrm{mg} / \mathrm{kg} / \mathrm{day}]$ ) for immunosuppression. About 4 years after the diagnosis of nephrotic syndrome had been made, an embryonal rhabdomyosarcoma developed on her tongue. The cancer was treated with TPOG-RMS-LR protocol, with vincristine, actinomycin, and cyclophosphamide. Magnetic resonance imaging scan, performed about 3 years after the start of TPOG-RMS-LR therapy, revealed complete remission of the cancer.
\end{abstract}

Conclusions: Although treatment with cyclosporine cannot be conclusively implicated as the cause the rhabdomyosarcoma in this patient, the association should prompt consideration of its use in the treatment of frequently relapsing nephrotic syndrome in children.

Keywords: Childhood nephrotic syndrome, Cyclosporine, Immunosuppressive therapy, Rhabdomyosarcoma, Case report

\footnotetext{
* Correspondence: yuanyow@mail.ncku.edu.tw

${ }^{3}$ Division of Pediatric Nephrology, Department of Pediatrics, National Cheng Kung University Hospital, Tainan, Taiwan

${ }^{4}$ Institute of Clinical Medicine, Medical College, National Cheng Kung

University, 138 Sheng-Li Road, Tainan 704, Taiwan

Full list of author information is available at the end of the article
}

(C) The Author(s). 2020 Open Access This article is licensed under a Creative Commons Attribution 4.0 International License, which permits use, sharing, adaptation, distribution and reproduction in any medium or format, as long as you give appropriate credit to the original author(s) and the source, provide a link to the Creative Commons licence, and indicate if changes were made. The images or other third party material in this article are included in the article's Creative Commons licence, unless indicated otherwise in a credit line to the material. If material is not included in the article's Creative Commons licence and your intended use is not permitted by statutory regulation or exceeds the permitted use, you will need to obtain permission directly from the copyright holder. To view a copy of this licence, visit http://creativecommons.org/licenses/by/4.0/ The Creative Commons Public Domain Dedication waiver (http://creativecommons.org/publicdomain/zero/1.0/) applies to the data made available in this article, unless otherwise stated in a credit line to the data. 


\section{Background}

Nephrotic syndrome is defined by nephrotic-range proteinuria $(\geq 40 \mathrm{mg} / \mathrm{m} 2 / \mathrm{h}$ or urine protein/creatinine ratio $\geq 200 \mathrm{mg} / \mathrm{mL}$ or $3+$ protein on urine dipstick), hypoalbuminemia $(<25 \mathrm{~g} / \mathrm{L})$ and edema [1]. The reported incidence of idiopathic nephrotic syndrome is 1.15-16.9 per 100,000 children, varying by ethnicity and region [2]. The cause remains unknown, but the pathogenesis is thought to involve immune dysregulation, systemic circulating factors, or inherited structural abnormalities of the podocyte. The disease most often resolves spontaneously, but corticosteroids often are required. About 1$3 \%$ of children with nephrotic syndrome have frequent relapses or steroid-dependent nephrotic syndrome. Resistance to steroids or steroid toxicity often prompts administration of other immunosuppressive drugs, such as cyclosporine (CsA), cyclophosphamide, rituximab [3]. and others. Rhabdomyosarcoma (RMS) is the kind of soft tissue sarcoma (STS) and most common occurs in children and adolescents [4]. RMS is accounting for $4.5 \%$ of all children cancer cases and the incidence is around 6 cases per million per year [5]. However, the aetiology of RMS is still need to be identified. Although tumorigenesis risks have not been found in children with nephrotic syndrome treated with CsA, one of the most feared adverse effects of the drug is de novo cancers $[6,7]$. Herein we describe a patient with frequently relapsing nephrotic syndrome who received a long course of CsA and developed a rhabdomyosarcoma (RMS) of the tongue.

\section{Case presentation}

A 2-year-4-month-old girl was referred to our hospital about 1 month after the diagnosis of nephrotic syndrome with relapse had been made: urine proteincreatinine ratio markedly increased $(749.1 \mathrm{mg} / \mathrm{mg})$; blood urea nitrogen $11 \mathrm{mg} / \mathrm{dL}$; serum creatinine $0.3 \mathrm{mg}$ / $\mathrm{dL}$; and serum albumin $1.8 \mathrm{~g} / \mathrm{dL}$. Proteinuria resolved on treatment with daily prednisolone for 4 weeks at the dose of $45 \mathrm{mg}(2 \mathrm{mg} / \mathrm{kg}) /$ day $)$ but recurred with taper from $25 \mathrm{mg}$ /day to $10 \mathrm{mg} /$ day (spot proteinuria $\geq 300$ $\mathrm{mg} / \mathrm{dL}$ protein).

A second relapse occurred near 3 months after the first when the daily dose of prednisolone was decreased and proteinuria resolved with prednisolone at $45 \mathrm{mg}$ /day for nearly a week.

A third relapse occurred 3 months after the second when she had taken $30 \mathrm{mg}$ prednisolone once every 2 days for 3 weeks (spot proteinuria $>500 \mathrm{mg} / \mathrm{dL}$ ). CsA was added at a daily dose of $50 \mathrm{mg} /$ day $(1.7 \mathrm{mg} / \mathrm{kg} /$ day $)$. Prednisolone was tapered over 3 months and discontinued after about 1 years of regular use. CsA was prescribed continuously, with the dose of $50 \mathrm{mg} /$ day since no proteinuria was noted. After a year of CsA maintenance without steroid, she developed bilateral leg edema, massive proteinuria, and decreased urine output. The dose of CsA was increased to $75 \mathrm{mg} /$ day $(3 \mathrm{mg} / \mathrm{kg} /$ day) for 4 months. The proteinuria resolved within 2 weeks under the combination of prednisolone $45 \mathrm{mg} /$ day and CsA $75 \mathrm{mg} /$ day, tapered to $50 \mathrm{mg} /$ day for another 3 months.

The fifth relapse, 9 months from the previous relapse, occurred (spot proteinuria $100 \mathrm{mg} / \mathrm{dl}$ ) after she had been prednisolone free for nearly 20 days. Since the fifth replace, the prednisolone was held at dose $60 \mathrm{mg} /$ day and cyclosporine was prescribed with dose $100 \mathrm{mg} /$ day.

Before CsA was replaced with mycophenolic acid 720 $\mathrm{mg} /$ day $(20 \mathrm{mg} / \mathrm{kg})$. The sixth relapse has occurred since daily dose of steroid was discontinued, and the proteinuria was controled by undertake prednisolone $45 \mathrm{mg} /$ day. She has had frequent urinary tract infections during the four-year use of steroids with other steroid-sparing immunosuppressive therapy.

At about 4 years after the diagnosis of nephrotic syndrome was made, reddish flat-topped masses appeared her tongue (Fig. 1). Curative wedge resection revealed an exophytic polypoid lesion that was histopathologically diagnosed embryonal RMS. After total excision of the tumor, she was treated according to TPOG-RMS-LR protocol, with vincristine, actinomycin, and cyclophosphamide (VAC). Mycophenolic acid and prednisolone were discontinued since the dose and duration of cyclophosphamide per TPOG protocol was more than the required amount for treatment of nephrotic syndrome. No proteinuria or nephrotic syndrome were noted during the 48-week VAC treatment and 10 months thereafter. The length and cumulative dosage of these immunosuppressive drugs are illustrated as supplemental figure 1.

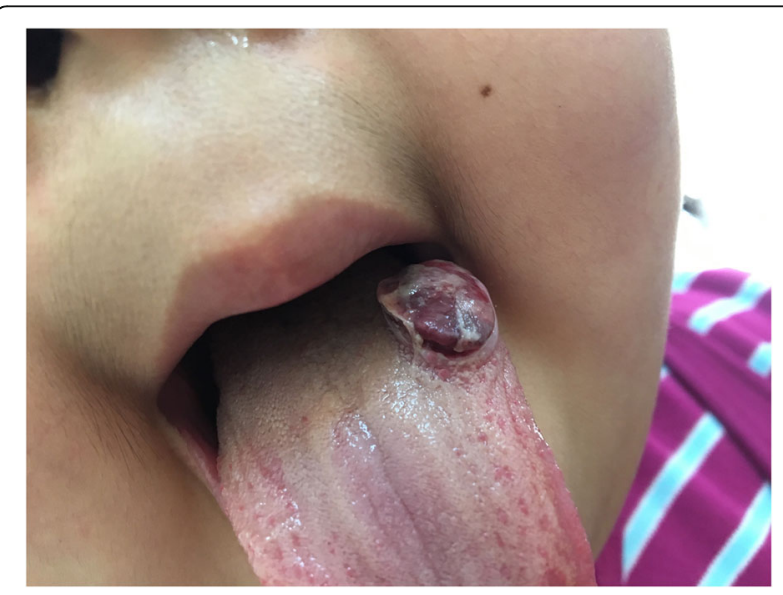

Fig. 1 A reddish flat-topped mass on the tongue 


\section{Discussion and conclusions}

We know of no other reports of RMS in children treated with CsA for nephrotic syndrome, although a case of embryonal RMS in pediatric nephrotic syndrome without evident immunosuppressive therapy has been described [8]. CsA has been widely accepted in the treatment of frequent relapsing nephrotic syndrome in children $[9,10]$. It is reported effective and safe in treatment of that condition to avoid the toxicity of corticosteroids [10]. Nevertheless, because of cyclosporine's risk in a wide variety of cancers, including RMS [6, 7, 11-13], even an isolated case of RMS in a child with nephrotic syndrome should prompt caution about its use in that population.

CsA may promote tumor angiogenesis through VEGF and blockake $\mathrm{T}$ lymphocytes function under high-dose CsA $(\geq 4-5 \mathrm{mg} / \mathrm{kg} /$ day) treatment [14]. The present study expanded this finding and further showed that CsA-related RMS has been described only in case reports (Table 1). Cescon et al. [11] reported a 23-yearold girl who received CsA for liver transplantation immunosuppression and later developed orbital embryonal RMS. A 47-year-old Japanese man, who received CsA for treatment of Behçet's disease, developed a malignant rhabdoid tumor in his posterior femoral region 3 years later [12]. A 15-year-old boy, treated with CsA to prevent kidney transplant rejection, developed RMS of the nasopharynx [13]. The tumors of our patient and the patient of Cescon et al. [11] were of the embryonal histology, which is the most common subtype. Mycophenolate mofetil (MMF), an ester prodrug of mycophenolic acid (MPA), is known as an FDA-approved immunosuppression agent and exists the function of anti-tumor activity, which mainly acts on inosine monophosphate dehydrogenase (IMDPH) to treat with immune-related adverse events effectively $[15,16]$.
Thus, utilizing CsA may exert the risk in promoting tumorigenesis during the treatment course of disease.

Although over $95 \%$ of RMSs arise de novo, the role of immunosuppressants in their causation-- especially in transplant patients, who require high dose and lifelong administration -- is persuasive. Further evidence of cyclosporine's oncogenic potential is that patients receiving reduced-dose of drug have had a lower risk of malignancies than did those receiving full-dose [17]. There is no solid evidence supporting an oncogenic effect of CsA in pediatric RMS, but other carcinogenic factors have not been identified. Molecular mechanisms of cyclosporine's tumor- promoting activity are incompletely defined. However, in human studies, CsA induced cancer progression via increasing production of TGF-beta and inhibiting Tlymphocyte function, and, in a murine model, T-cellbased therapy was effective in treating RMS [18]. These results suggest that defective $\mathrm{T}$-cell immunity contributes to rhabdomyosarcoma oncogenesis. CsA also has caused defective nucleotide excision repair in cells [19]. However, RMS has been thought as the dominant hereditary genetic diseases [20], but some risk factors may trigger the occurrence of RMS including, the familial syndromes (Li-Fraumeni syndrome), the sign with a lump or swelling and keep getting bigger, and bulging eyes or hematuria. Otherwise, lifestyle-related risk factors, for examples, body weight, diet and physical activity, may not play a role in the occurrence of RMS, which is commonly occurred in childhood (under 10 years old). Altogether, the present case report suggests that the risk, albeit low, of rhabdomyosarcoma with cyclosporine immunosuppression be considered in the selection of immunotherapeutic agents in the treatment of relapsing nephrotic syndrome in children.

Table 1 Case reports on cyclosporine associated rhabdomyosarcoma or rhabdoid tumor

\begin{tabular}{|c|c|c|c|c|c|c|c|c|}
\hline Year, Author & $\begin{array}{l}\text { Patient } \\
\text { data }\end{array}$ & $\begin{array}{l}\text { Indication for } \\
\text { CsA }\end{array}$ & $\begin{array}{l}\text { Dosage (mg/ } \\
\text { kg/day) }\end{array}$ & $\begin{array}{l}\text { Duration of } \\
\text { CsA }\end{array}$ & $\begin{array}{l}\text { Exposure to } \\
\text { Diagnosis }\end{array}$ & Tumor type, location & $\begin{array}{l}\text { RMS } \\
\text { treatment }\end{array}$ & $\begin{array}{l}\text { treatment } \\
\text { response }\end{array}$ \\
\hline Current case & $\begin{array}{l}8 \mathrm{y} / \mathrm{o} \\
\text { female }\end{array}$ & $\begin{array}{l}\text { nephrotic } \\
\text { syndrome }\end{array}$ & $1.8-3.0$ & 3 years & 4 years 2 months & embryonal, tongue & $\begin{array}{l}\text { Resection } \\
\text { VAC } \\
\text { ( } 48 \text { weeks) }\end{array}$ & $\begin{array}{l}\text { Complete } \\
\text { remission } \\
\text { ( } 27 \text { months) }\end{array}$ \\
\hline $\begin{array}{l}\text { 2003, Cescon } \\
{[11]}\end{array}$ & $\begin{array}{l}23 \mathrm{y} / \mathrm{o} \\
\text { female }\end{array}$ & liver transplant & 13.0 & 16 months & 16 months & embryonal, orbit & $\begin{array}{l}\text { RT } \boldsymbol{\Delta} \\
\text { VAC } \\
\text { (24 weeks) }\end{array}$ & $\begin{array}{l}\text { Stable Disease } \\
\text { (38 months) }\end{array}$ \\
\hline $\begin{array}{l}\text { 1998, } \\
\text { Muramatsu [12] }\end{array}$ & $\begin{array}{l}47 \text { y/o } \\
\text { male }\end{array}$ & $\begin{array}{l}\text { Behçet's } \\
\text { disease }\end{array}$ & 5.0 & 9 months $\nabla$ & 3 years & $\begin{array}{l}\text { malignant rhabdoid } \\
\text { tumor, femur }\end{array}$ & $\begin{array}{l}\text { Resection } \\
\text { RT }\end{array}$ & $\begin{array}{l}\text { Complete } \\
\text { remission } \\
\text { (36 months) }\end{array}$ \\
\hline 1991, Piller [13] & $\begin{array}{l}15 \mathrm{y} / \mathrm{o} \\
\text { male }\end{array}$ & $\begin{array}{l}\text { renal } \\
\text { transplant }\end{array}$ & $\mathrm{N} / \mathrm{A}$ & 23 months & 23 months & $\begin{array}{l}\text { rhabdomyosarcoma, } \\
\text { nasopharynx }\end{array}$ & $\mathrm{N} / \mathrm{A}$ & $\mathrm{N} / \mathrm{A}$ \\
\hline
\end{tabular}




\section{Supplementary Information}

The online version contains supplementary material available at https://doi. org/10.1186/s12882-020-02136-6.

Additional file 1: Figure S1. Schematic the time line of different drugs utilized in treatment of nephrotic syndrome patient with RSM.

\section{Abbreviations}

RMS: Rhabdomyosarcoma; CsA: Cyclosporine; TPOG-RMS-LR: Taiwan Pediatric Oncology Group-RMS-Low risk group; VAC: Vincristine, actinomycin, and cyclophosphamide; VEGF: Vascular endothelial growth factor

\section{Acknowledgements}

None.

\section{Authors' contributions}

YYC had made substantial contributions to the conception and study design; HGW and YYC collected the data; HGW and YYC analyzed the data; HGW CNC, JSC, and YYC prepared the manuscript and critical revision of the manuscript; all authors read and approved the final version for submission.

\section{Funding}

None.

\section{Availability of data and materials}

The data used to support the findings of this study are included within the article.

\section{Ethics approval and consent to participate}

Institutional review board of National Cheng Kung University Hospital approval to publish this information was obtained (No. A-EC-109-015). The written informed consent was provided by the patient's parent for participation in this study at National Cheng Kung University Hospital.

\section{Consent for publication}

Not applicable

\section{Competing interests}

The authors declare that they have no competing interests.

\section{Author details}

${ }^{1}$ Eudcation Center, National Cheng Kung University Hospital, Tainan, Taiwan. ${ }^{2}$ Division of Pediatric Hematology, Department of Pediatrics, College of Medicine, National Cheng Kung University Hospital, Tainan, Taiwan. ${ }^{3}$ Division of Pediatric Nephrology, Department of Pediatrics, National Cheng Kung University Hospital, Tainan, Taiwan. ${ }^{4}$ Institute of Clinical Medicine, Medical College, National Cheng Kung University, 138 Sheng-Li Road, Tainan 704, Taiwan.

Received: 24 June 2020 Accepted: 29 October 2020

Published online: 17 November 2020

\section{References}

1. Downie ML, Gallibois C, Parekh RS, Noone DG. Nephrotic syndrome in infants and children: pathophysiology and management. Paediatr Int Child Health. 2017;37(4):248-58.

2. Noone DG, lijima K, Parekh $R$. Idiopathic nephrotic syndrome in children. Lancet. 2018;392(10141):61-74.

3. Kari JA, Alhasan KA, Albanna AS, Safdar OY, Shalaby MA, Bockenhauer D, ElDesoky SM. Rituximab versus cyclophosphamide as first steroid-sparing agent in childhood frequently relapsing and steroid-dependent nephrotic syndrome. Pediatr Nephrol. 2020;35:1445.

4. Malempati S, Hawkins DS. Rhabdomyosarcoma: review of the Children's oncology group (COG) soft-tissue sarcoma committee experience and rationale for current COG studies. Pediatr Blood Cancer. 2012;59(1):5-10.

5. Chou SW, Chang HH, Lu MY, Yang YL, Lin DT, Lin KH, Jou ST. Clinical outcomes of pediatric patients with newly diagnosed rhabdomyosarcoma treated by two consecutive protocols - a single institution report in Taiwan. J Formos Med Assoc. 2019;118(1 Pt 2):332-40.
6. Andre N, Roquelaure B, Conrath J. Molecular effects of cyclosporine and oncogenesis: a new model. Med Hypotheses. 2004;63(4):647-52.

7. Walsh SB, Xu J, Xu H, Kurundkar AR, Maheshwari A, Grizzle WE, Timares L, Huang CC, Kopelovich L, Elmets CA, et al. Cyclosporine a mediates pathogenesis of aggressive cutaneous squamous cell carcinoma by augmenting epithelial-mesenchymal transition: role of TGFbeta signaling pathway. Mol Carcinog. 2011;50(7):516-27.

8. Olowu WA, Salako AA, Adelusola KA, Sowande OA, Adetiloye VA, Adefehint O, Osasan SA. Focal segmental glomerulosclerosis and nephrotic syndrome in a child with embryonal rhabdomyosarcoma. Clin Exp Nephrol. 2008;12(2): 144-8.

9. Hamasaki Y, Komaki F, Ishikura K, Hamada R, Sakai T, Hataya H, Ogata K, Ando T, Honda M. Nephrotoxicity in children with frequently relapsing nephrotic syndrome receiving long-term cyclosporine treatment. Pediatr Nephrol. 2017:32(8):1383-90.

10. Ishikura K, Ikeda M, Hattori S, Yoshikawa N, Sasaki S, lijima K, Nakanishi K, Yata N, Honda M. Effective and safe treatment with cyclosporine in nephrotic children: a prospective, randomized multicenter trial. Kidney Int 2008;73(10):1167-73.

11. Cescon M, Grazi GL, Assietti R, Scanni A, Frigerio F, Sparacio F, Ercolani G, Cavallari A. Embryonal rhabdomyosarcoma of the orbit in a liver transplant recipient. Transpl Int. 2003:16(6):437-40.

12. Muramatsu M, Kotake S, Yoshikawa K, Sasamoto Y, Matsuda H, Yamawaki S. The development of malignant rhabdoid tumor in a patient with Behcet's disease treated with ciclosporin. Graefes Arch Clin Exp Ophthalmol. 1998; 236(10):798-9.

13. Piller P, Herman D, Stierle $J$, Conraux C. Rhabdomyosarcoma of the nasopharynx occurring with immunosuppressive treatment with cyclosporin a. apropos of a case. Ann Otolaryngol Chir Cervicofac. 1991;108(1):38-40.

14. Flores C, Fouquet G, Moura IC, Maciel TT, Hermine O. Lessons to learn from low-dose Cyclosporin-a: a new approach for unexpected clinical applications. Front Immunol. 2019;10:588.

15. Majd N, Sumita K, Yoshino H, Chen D, Terakawa J, Daikoku T, Kofuji S, Curry $\mathrm{R}$, Wise-Draper TM, Warnick RE, et al. A review of the potential utility of mycophenolate mofetil as a cancer therapeutic. J Cancer Res. 2014:423401.

16. Simsek M, Tekin SB, Bilici M. Immunological agents used in Cancer treatment. Eurasian J Med. 2019:51(1):90-4.

17. Kahan BD, Yakupoglu YK, Schoenberg L, Knight RJ, Katz SM, Lai D, Van Buren CT. Low incidence of malignancy among sirolimus/cyclosporinetreated renal transplant recipients. Transplantation. 2005;80(6):749-58.

18. Hojo M, Morimoto T, Maluccio M, Asano T, Morimoto K, Lagman M, Shimbo T, Suthanthiran M. Cyclosporine induces cancer progression by a cellautonomous mechanism. Nature. 1999;397(6719):530-4.

19. Kuschal C, Thoms KM, Boeckmann L, Laspe P, Apel A, Schon MP, Emmert S. Cyclosporin a inhibits nucleotide excision repair via downregulation of the xeroderma pigmentosum group a and $\mathrm{G}$ proteins, which is mediated by calcineurin inhibition. Exp Dermatol. 2011;20(10):795-9.

20. Kerin U, Wolohan C, Cooke K. Rhabdomyosarcoma: an overview and nursing considerations. Br J Nurs. 2018;27(6):328-32.

\section{Publisher's Note}

Springer Nature remains neutral with regard to jurisdictional claims in published maps and institutional affiliations.

Ready to submit your research? Choose BMC and benefit from:

- fast, convenient online submission

- thorough peer review by experienced researchers in your field

- rapid publication on acceptance

- support for research data, including large and complex data types

- gold Open Access which fosters wider collaboration and increased citations

- maximum visibility for your research: over $100 \mathrm{M}$ website views per year

At BMC, research is always in progress.

Learn more biomedcentral.com/submission 